\title{
Vinasse from Sugarcane Ethanol Production: Better Treatment or Better Utilization?
}

\author{
Cristiano E. Rodrigues Reis and Bo Hu* \\ Department of Bioproducts and Biosystems Engineering, University of Minnesota, Saint Paul, MN, USA
}

Ethanol production from sugarcane in Brazil is a well-established industry, with relatively simple operations and high yield. The ethanol primarily serves as a renewable fuel blending with gasoline and diesel to increase the energy security in Brazil. Several environmental concerns are emerged around the by-products from this industry. Vinasse, the liquid fraction generated from the rectification and distillation operations of ethanol, is a sulfur-rich, low pH, dark-colored, and odorous effluent, produced at volumes as high as 20-fold of ethanol. Traditional wastewater treatments, such as bioprocessing, advanced oxidative processes, anaerobic digestion (AD), and chemical-based processes, have been applied to vinasse management. Despite most of its utilization being in fertirrigation practices, vinasse may represent a key factor in enhancing profitability and environmental outcomes of a sugarcane-to-ethanol plant. The application of some upgrade solutions to sugarcane-derived vinasse may represent additional sources of energy, production

OPEN ACCESS

Edited by:

Rongxin Su,

Tianjin University, China

Reviewed by:

Chao Ma,

Bristol Myers Squibb, USA

Renliang Huang,

Tianjin University, China

*Correspondence: $\mathrm{Bo} \mathrm{Hu}$

bhu@umn.edu

Specialty section:

This article was submitted to Bioenergy and Biofuels,

a section of the journal Frontiers in Energy Research

Received: 13 February 2017 Accepted: 23 March 2017 Published: 10 April 2017

Citation:

Rodrigues Reis CE and Hu B (2017) Vinasse from Sugarcane Ethanol Production: Better Treatment or Better Utilization?

Front. Energy Res. 5:7. doi: 10.3389/fenrg.2017.00007 of animal feed components, and reduction in water consumption within a plant. The use of mature technologies, yet not widespread in the sugarcane-to-ethanol industry, could help attenuate environmental concerns. Oxidation and chemical processes, AD, and microbial fermentation have been presented as alternative impactful alternatives to (i) reduce its organic and mineral load, converting it to a feedstock with fewer environmental applications when applied as fertilizer and (ii) to convert organic matter and nutrients to a nutritious biomass, simultaneously increasing water reclamation potential by plants. This mini-review article provides a critical and comprehensive summary of the alternatives developed or under development to vinasse management.

Keywords: vinasse, sugarcane, anaerobic digestion, fertirrigation, ethanol

\section{INTRODUCTION}

Brazil is home to over 300 active sugarcane biorefineries (Filoso et al., 2015), with an ethanol-rich history dating back to the 1970s (Goldemberg et al., 2008). The oil embargo crises over 40 years ago forced the Brazilian government to find alternative solutions for energy generation. The most successful strategy was the National Ethanol Program (Proálcool), which increased Brazil's energy security and posed it as the largest ethanol producer for decades (Goldemberg et al., 2008). Even with recent global booming of ethanol and biofuel industry, Brazil is still the second largest ethanol producer in the world, summing values of 25 billion L per year (Walter et al., 2011). Sugarcane-toethanol productivity reaches about $5.6 \mathrm{~m}^{3} \mathrm{ha}^{-1}$ over the course of a year (Badger, 2002).

Over $75 \%$ of the Brazilian distilleries operate using the Melle-Boinot process, a fed-batch system using yeast cell recycling. Yeast cells are collected at the end of the fermentation cycle and are either centrifuged or filtered, and reinoculated to the next fermentation cycle (Brethauer 
and Wyman, 2010). The high-density cell culture and simple composition of sugarcane juice allow a quick fermentation cycle (6-10 h) and low cell growth rates (Della-Bianca et al., 2013). The upstream steps include a sulfitation process, which enrich the downstream products with sulfur compounds, especially sulfate species (Della-Bianca et al., 2013). After fermentation, the fermented juice is processed into an ethanol stream and a liquid-rich by-product-vinasse.

Sugarcane vinasse is a residue from the sugar-ethanol industry, characterized as being an acidic suspension, high COD values, unpleasant odors, and dark brown color (Gómez and Rodríguez, 2000; Jiang et al., 2012; Christofoletti et al., 2013). The characteristics of vinasse are largely dependent on the feedstock, and on the fermentation and distillation conditions applied (España-Gamboa et al., 2011). A summary of vinasse composition is presented in Table 1. Sugarcane vinasse is reported to be a nitrogen-deficient medium, which is most composed as acid-insoluble nitrogen (Parnaudeau et al., 2008). Vinasse is also characterized as a feedstock rich in phenolic compounds and melanoidins (FitzGibbon et al., 1998). Using NMR and FTIR, Benke et al. (1998) detected levels of cellulose and hemicellulose in vinasse, which are derived from the grinding conditions of sugarcane. Recent development on lignocellulosic ethanol production from sugarcane bagasse may further increase the fiber content of vinasse, as that the various methods applied to sugarcane bagasse pretreatment will likely affect the production of liquid byproducts (Moraes et al., 2015). Until now, there is a lack of information regarding the composition of liquid streams generated as by-products, except for a patent application (Cammarota et al., 2012). The composition of second-generation vinasse contains greater organic matter content and similar BOD/COD ratios (Table 1). Mineral composition, especially for potassium, is significantly lower.

Vinasse has been mostly used on fertirrigation practices, i.e., utilizing it as a liquid fertilizer for crops, reducing the water input for plant growth (Walter et al., 2011). Fertirrigation usually has negative effects on soil and ground waters in the long term (Rocha et al., 2007). A few adequate uses for vinasse management have been identified and used in large-scale operations, such as vinasse recycling to fermentation streams (Fadel et al., 2014; Yang et al., 2016), fertirrigation (Christofoletti et al., 2013; Filoso et al., 2015), energy production (Cortez et al., 1992; Walter et al., 2011), and animal feed production (Cortez et al., 1992). Recently, studies

TABLE 1 | Composition of sugarcane vinasse from first and second generation sugarcane-to-ethanol production.

\begin{tabular}{|c|c|c|c|c|c|}
\hline \multicolumn{3}{|c|}{ Mineral analysis } & \multicolumn{3}{|c|}{ Organic analysis } \\
\hline Component & Value & Reference & Component & Value & Reference \\
\hline $\mathrm{Cl}^{-}\left(\mathrm{mg} \mathrm{L}^{-1}\right)$ & $59.4^{\mathrm{a}}$ & dos Santos et al. (2013) & Organic matter (\%) & $3.96^{\mathrm{a}}$ & Mariano et al. (2009) \\
\hline $\mathrm{SO}_{4}^{2-}\left(\mathrm{mg} \mathrm{L}^{-1}\right)$ & $1,680^{a}, 44-366^{b}$ & $\begin{array}{l}\text { dos Santos et al. (2013), } \\
\text { Cammarota et al. (2012) }\end{array}$ & $\mathrm{C}: \mathrm{N}$ ratio & $10^{\mathrm{a}}, 49.2-124.9^{\mathrm{b}}$ & $\begin{array}{l}\text { Mariano et al. (2009), } \\
\text { Cammarota et al. (2012) }\end{array}$ \\
\hline $\mathrm{Na}^{+}\left(\mathrm{mg} \mathrm{L}^{-1}\right)$ & $8.6^{a}$ & dos Santos et al. (2013) & $\mathrm{COD}\left(\mathrm{mg} \mathrm{L}^{-1}\right)$ & $32,000-92,800^{a}, 75,800-109,700^{b}$ & $\begin{array}{l}\text { Mariano et al. (2009), Paz-Pino } \\
\text { et al. (2014), Cammarota } \\
\text { et al. (2012) }\end{array}$ \\
\hline $\mathrm{K}^{+}\left(\mathrm{mg} \mathrm{L}^{-1}\right)$ & $1,620^{\mathrm{a}}$ & dos Santos et al. (2013) & $\mathrm{BOD}_{5}\left(\mathrm{mgO}_{2} \mathrm{~L}^{-1}\right)$ & $13,514-36,847^{\mathrm{a}}, 31,500-87,700^{\mathrm{b}}$ & Paz-Pino et al. (2014) \\
\hline $\mathrm{Ca}^{2+}\left(\mathrm{mg} \mathrm{L}^{-1}\right)$ & $3,160^{a}$ & dos Santos et al. (2013) & $\mathrm{BOD}_{5} / \mathrm{COD}$ & $0.18-0.34^{\mathrm{a}}, 0.39-0.80^{\mathrm{b}}$ & $\begin{array}{l}\text { Paz-Pino et al. (2014), } \\
\text { Cammarota et al. (2012) }\end{array}$ \\
\hline $\mathrm{Mg}^{2+}\left(\mathrm{mg} \mathrm{L}^{-1}\right)$ & $162.4^{\mathrm{a}}$ & dos Santos et al. (2013) & Phenols (mg L-1) & $230-390^{a}, 0.4-12.4^{b}$ & $\begin{array}{l}\text { Paz-Pino et al. (2014), } \\
\text { Cammarota et al. (2012) }\end{array}$ \\
\hline $\mathrm{PO}^{3-}\left(\mathrm{mg} \mathrm{L}^{-1}\right)$ & $560^{a}, 33.26^{b}$ & $\begin{array}{l}\text { dos Santos et al. (2013), } \\
\text { Cammarota et al. (2012) }\end{array}$ & $\mathrm{NH}_{4}^{+}\left(\mathrm{mg} \mathrm{L}^{-1}\right)$ & $23.9^{a}$ & dos Santos et al. (2013) \\
\hline $\mathrm{NO}_{3}^{-}\left(\mathrm{mg} \mathrm{L}^{-1}\right)$ & $823.7^{a}$ & dos Santos et al. (2013) & Protein (\%) & $2.92^{\mathrm{a}}$ & Dowd et al. (1994) \\
\hline $\mathrm{Fe}\left(\mathrm{mg} \mathrm{L}^{-1}\right)$ & $44.9^{\mathrm{a}}$ & dos Santos et al. (2013) & Fiber (\%) & $0.2^{\mathrm{a}}$ & Dowd et al. (1994) \\
\hline $\mathrm{Mn}\left(\mathrm{mg} \mathrm{L}^{-1}\right)$ & $4.9^{a}$ & dos Santos et al. (2013) & Fat (\%) & $0.41^{\mathrm{a}}$ & Dowd et al. (1994) \\
\hline $\mathrm{Zn}\left(\mathrm{mg} \mathrm{L}^{-1}\right)$ & $1.2^{\mathrm{a}}$ & dos Santos et al. (2013) & Ash (\%) & $3.61^{\mathrm{a}}$ & Dowd et al. (1994) \\
\hline $\mathrm{BO}_{3}^{3-}\left(\mathrm{mg} \mathrm{L}^{-1}\right)$ & $1.94^{\mathrm{a}}$ & dos Santos et al. (2013) & Carbohydrate (\%) & $3.42^{\mathrm{a}}$ & Dowd et al. (1994) \\
\hline $\mathrm{Ba}\left(\mathrm{mg} \mathrm{L}^{-1}\right)$ & $0.54^{\mathrm{a}}$ & Mariano et al. (2009) & Acetaldehyde $\left(\mathrm{g} \mathrm{L}^{-1}\right)$ & $0.697^{a}$ & Dowd et al. (1994) \\
\hline $\mathrm{Cd}\left(\mathrm{mg} \mathrm{L}^{-1}\right)$ & $1.06^{\mathrm{a}}$ & Mariano et al. (2009) & Ethanol $\left(g \mathrm{~L}^{-1}\right)$ & $3.83^{\mathrm{a}}$ & Dowd et al. (1994) \\
\hline $\mathrm{Cr}\left(\mathrm{mg} \mathrm{L}^{-1}\right)$ & $0.15^{\mathrm{a}}$ & Mariano et al. (2009) & Propylene glycol (g $\left.\mathrm{L}^{-1}\right)$ & $0.084^{a}$ & Dowd et al. (1994) \\
\hline $\mathrm{Ni}\left(\mathrm{mg} \mathrm{L}^{-1}\right)$ & $0.26^{a}$ & Mariano et al. (2009) & 2,3-butanediols $\left(\mathrm{g} \mathrm{L}^{-1}\right)$ & $0.568^{a}$ & Dowd et al. (1994) \\
\hline $\mathrm{Al}\left(\mathrm{mg} \mathrm{L}^{-1}\right)$ & $72.5^{\mathrm{a}}$ & Mariano et al. (2009) & Glycerol $\left(g L^{-1}\right)$ & $5.86^{\mathrm{a}}$ & Dowd et al. (1994) \\
\hline $\mathrm{MoO}_{4}^{2-}\left(\mathrm{mg} \mathrm{L}^{-1}\right)$ & $0.17^{a}$ & dos Santos et al. (2013) & Erythritol $\left(\mathrm{g} \mathrm{L}^{-1}\right)$ & $0.088^{a}$ & Dowd et al. (1994) \\
\hline $\mathrm{Cu}\left(\mathrm{mg} \mathrm{L}^{-1}\right)$ & $0.06^{a}$ & Mariano et al. (2009) & Arabinitol $\left(g L^{-1}\right)$ & $0.064^{a}$ & Dowd et al. (1994) \\
\hline \multicolumn{6}{|c|}{ Physicochemical analysis } \\
\hline Density $\left(\mathrm{g} \mathrm{mL}^{-1}\right)$ & $1^{\mathrm{a}}$ & Mariano et al. (2009) & Chiro-inositol $\left(\mathrm{g} \mathrm{L}^{-1}\right)$ & $0.114^{\mathrm{a}}$ & Dowd et al. (1994) \\
\hline $\mathrm{Ph}$ & $4.84^{\mathrm{a}}, 4.0-4.9^{\mathrm{b}}$ & Dowd et al. (1994) & Sucrose $\left(g L^{-1}\right)$ & $0.222^{a}$ & Dowd et al. (1994) \\
\hline $\mathrm{DO}\left(\mathrm{mg} \mathrm{L}^{-1}\right)$ & $4.3^{\mathrm{a}}$ & Mariano et al. (2009) & Acetic acid $\left(\mathrm{g} \mathrm{L}^{-1}\right)$ & $1.56^{\mathrm{a}}$ & Dowd et al. (1994) \\
\hline Moisture (\%) & $89.64^{a}$ & Dowd et al. (1994) & Formic acid $\left(g L^{-1}\right)$ & $0.582^{\mathrm{a}}$ & Dowd et al. (1994) \\
\hline Eh (Mv) & $260^{a}$ & Mariano et al. (2009) & Lactic acid $\left(g \mathrm{~L}^{-1}\right)$ & $7.74^{\mathrm{a}}$ & Dowd et al. (1994) \\
\hline $\begin{array}{l}\text { Conductivity } \\
\left(\mathrm{mS} \mathrm{cm}^{-1}\right)\end{array}$ & $8.52^{\mathrm{a}}$ & Mariano et al. (2009) & Quinic acid $\left(g \mathrm{~L}^{-1}\right)$ & $0.508^{a}$ & Dowd et al. (1994) \\
\hline
\end{tabular}

aFirst generation.

${ }^{b}$ Second generation. 
on transforming vinasse into a high value-added feedstock have also been performed (Nitayavardhana and Khanal, 2010).

Sugarcane and ethanol production in Brazil has been largely criticized due to several ecological factors (Sparovek et al., 2009), and negative environmental impacts, especially to the increase of contaminants in soil and surface water (Jiang et al., 2012). This review article describes some of the alternative uses to diminish the environmental impact by vinasse management practices, as shown in Figure 1.

\section{FERTIRRIGATION PRACTICES WITH VINASSE}

The utilization of vinasse in fertirrigation practices started in the 1950s (Valsechi and Gomes, 1954), and by the 1980s, it was a common practice for sugarcane refineries to utilize the liquid residual as fertilizer (Walter et al., 2011). The concept behind fertirrigation consists on a sum of irrigation to sugarcane fields, by the percolation of vinasse liquid to the soil, with the simultaneous fertilization, transferring its nutrients to the plants (Christofoletti et al., 2013). Besides decreasing the costs involved with chemical fertilizers (Jiang et al., 2012), completely supplying phosphorus (Moran-Salazar et al., 2016) and being of low capital cost, vinasse utilization in fertirrigation practices could be considered of certain level of environmental concern (Sparovek et al., 2009). Fertirrigation practices have been linked with increase in eutrophication of waterbodies and the formation of dead aquatic bodies in Brazil and in other countries (Eykelbosh et al., 2015). The correct application of fertirrigation has proven not to impact the physical, chemical, and biological properties of the soil to which vinasse is applied (Christofoletti et al., 2013), such as, and levels up to $300 \mathrm{~m}^{3}$ vinasse ha $\mathrm{h}^{-1}$ with potassium levels of 3-4 $\mathrm{kg} \mathrm{m}^{-3}$ do not impact negatively the soil (Penatti et al., 1988). However, conditions with increase in crop losses, soil $\mathrm{pH}$ change, increase in phytotoxicity, and release of sulfurous odors are not uncommon (Christofoletti et al., 2013).

Sugarcane crops occupy nearly three million hectares in the Brazilian state of São Paulo (Có Júnior et al., 2008). Current production of ethanol could supplement up to $80 \%$ of sugarcane plantation by fertirrigation (Christofoletti et al., 2013). A study conducted at the Pirapama basin river, home to three ethanol plants in Brazil, producing over 500,000 L of ethanol per day during the peak season, has estimated biochemical oxygen demand disposal rates of $226,335 \mathrm{~kg}$ on a daily basis, correspondent to a city of 4.2 million people (Alcoforado de Moraes et al., 2009). The high toxicity potential of vinasse being utilized in fertirrigation practices may lead to hydrologic, agronomic, and social problems. Since there are no pollution charges applied to sugarcane farmers and ethanol producers, fertirrigation still stands as the predominantly application of vinasse.

\section{VINASSE AS A FEEDSTOCK FOR BIOLOGICAL TREATMENT}

Vinasse typically has a moisture content of about 93\%, and the present organic solids and minerals, such as potassium, calcium, and magnesium (Christofoletti et al., 2013), may provide a rich culture medium for biological cultivation. Detoxification from soils contaminated by excessive vinasse utilization has been evaluated (Abioye, 2011), indicating that the organic

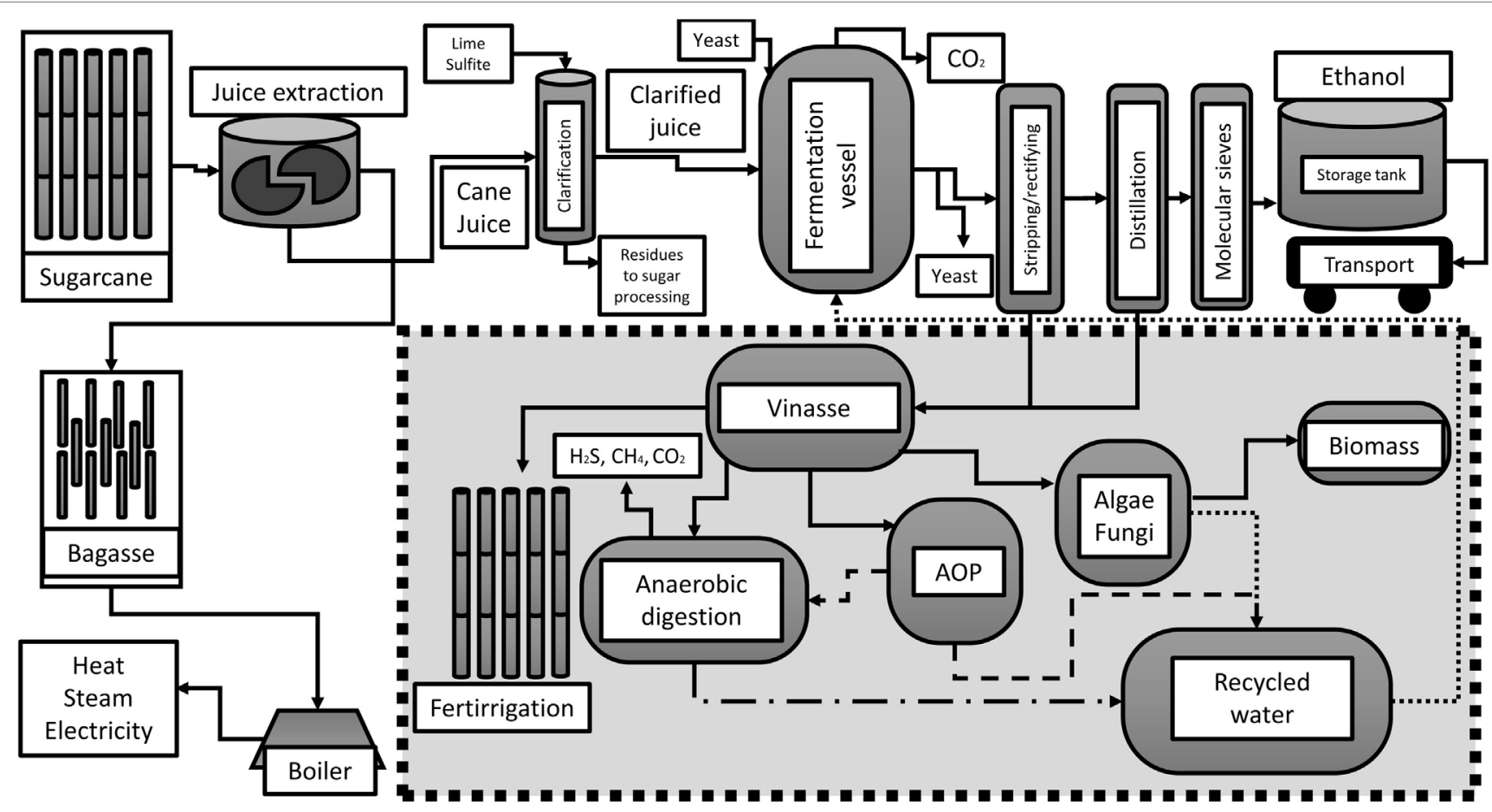

FIGURE 1 | Simplified sugarcane-to-ethanol process with potential modifications in vinasse management. 
compounds present in the effluent may serve as nutrient sources for microorganisms, despite the low concentration of nitrogen and phosphorus. Prata et al. (2001) also indicated that the readily available carbon sources in vinasse, such as glycerol, accelerated the degradation of the herbicide ametryn in vinassecontaminated soils.

In situ biological treatment of vinasse could be a potentially solution. Among different fungi that can utilize vinasse as a substrate for growth, Rhizopus oligosporus was grown on a vinasse-rich medium $(75 \% \mathrm{v} / \mathrm{v})$ using an airlift bioreactor (Nitayavardhana et al., 2013). The 2.5-L reactor used for the study had supplementation of nitrogen and phosphorus, and aeration rates ranging from 0.5 to $2.0 \mathrm{vvm}$, achieving a maximum biomass accumulation of $8.04 \mathrm{~g}$ of increase compared to the initial mycelium inoculated. Nitayavardhana et al. (2013) reported a decrease in $80 \%$ of COD and observed that the fungal biomass achieved a high accumulation of protein (around 50\%), which could be redirected to livestock production, especially since $R$. oligosporus cultivations usually yield amino acid profiles comparable to those of soybean meal (Lim and Akiyama, 1992), being only deficient in methionine and phenylalanine. $R$. oligosporus is a commonly used starter culture for Indonesian tempeh production and are known to fully utilize carbon sources rich in sucrose, as the one in vinasse, to grow (Egounlety and Aworh, 2003). Fungal treatment of with white-rot Trametes versicolor was performed in order to evaluate the fungus potential to produce laccase and decrease the concentration of phenol and chromophoric compounds in vinasse (España-Gamboa et al., 2015, 2017). Achieving 60\% removal of COD, and over $80 \%$ of total phenol, with a decrease in almost $20 \%$ in color, T. versicolor has proven to be excellent laccase-producing microorganisms, achieving production of 1,630 laccase units per liter of medium (España-Gamboa et al., 2015). Since the presence of melanoidins, phenols, and polyphenols have been described to potentially have negative effects on crop productions (Constabel and Ryan, 1998), bioprocessing technologies, such as the study using T. versicolor, can decrease the harmful effects of applying vinasse in fertirrigation.

Utilizing microorganisms to treat vinasse does not only serve for the purpose of reducing COD and toxic compounds. The utilization of fungi cultivated in vinasse potentially can bring additional revenue to sugarcane-based ethanol plants by providing feed and feed supplements to livestock production. Nair and Taherzadeh (2016) cultivated Neurospora intermedia and Aspergillus oryzae in vinasse and observed that an integration to a medium-sized facility, producing $100,000 \mathrm{~m}^{3}$ of ethanol a year, could reach up to 250,000 tons of protein-rich (45 weight \%) dry fungal biomass per year. $N$. intermedia and A. oryzae are characterized as generally regarded as safe materials (Ferreira et al., 2015; Todokoro et al., 2015) and have been traditionally used in the preparation of traditional dishes in Southeast and East Asia, being recently used in starch-based ethanol waste streams (Ferreira et al., 2015). Heterotrophic algae have also been reported as potential microorganisms to utilize the nutrients in vinasse to grow. The dark color characteristic to vinasse may be comparable to other dark effluents, such as municipal leachate, and may significantly hinder photoautotrophic growth of algae (Reis et al., 2014b). Therefore, heterotrophic growth may be the most appropriate growth mode for algae in vinasse. An example with green algae Desmodesmus sp. indicated slight elevation of $\mathrm{pH}$, low oxygen, and low carbon dioxide removal, with a decrease of $52.1 \%$ in nitrogen and $36.2 \%$ of COD. Desmodesmus also achieved high yield of COD to biomass in the first hour of growth $\left(0.5 \mathrm{~g} \mathrm{~g}^{-1}\right)$ and specific growth rate of $0.15 \mathrm{~h}^{-1}$. Scenedesmus sp. was cultivated on a Guillard-modified medium supplemented with $40 \%$ of vinasse and has been reported as able to grow in rates comparable to the control experiments (Ramirez et al., 2014).

Several opportunities used in starch-based ethanol research could be utilized with vinasse as bioprocess medium, such as those producing ethanol, malic acid, butanol, and many other commodity chemicals (Reis et al., 2017). The production of secondary ethanol using $N$. intermedia and $A$. oryzae on vinasse, for instance, would potentially provide extra $12.6 \%$ ethanol produced annually (Nair and Taherzadeh, 2016). The direct use of vinasse as feed material, in a similar fashion as the conditions applied to the U.S. dry-grind corn-to-ethanol industry, may not be suitable with the current composition of vinasse, especially due to the low protein content, and surplus of sulfur. An opportunity is to utilize protein-rich biomass grown in vinasse as animal feed, which may represent a significant change in the utilization of downstream processing of sugarcane-to-ethanol products. The utilization of fungal protein grown on sugarcane vinasse could provide feedstock for a market similar to soybean meal, generating at least USD 9.5 million annually to ethanol plants (Nitayavardhana and Khanal, 2010).

\section{ADDITION OF VALUE TO VINASSE VIA CHEMICAL AND ADVANCED OXIDATION PROCESSES (AOPS)}

Advanced oxidation process methods have been extensively used in wastewater treatment facilities, which principles lies behind the high reactivity of $\mathrm{HO} \bullet$ radicals, driving oxidation processes to all sorts of recalcitrant pollutants (Andreozzi et al., 1999). Utilizing AOP to treat vinasse is an opportunity to recycle the water back to the fermentation process, decreasing operational costs and environmental footprint of sugarcane plants. The effectiveness of ozone-based AOP $\left(\mathrm{O}_{3}, \mathrm{O}_{3} / \mathrm{UV}\right.$, and $\left.\mathrm{O}_{3} / \mathrm{UV} / \mathrm{H}_{2} \mathrm{O}_{2}\right)$ has been tested on a vinasse-like effluent, achieving a fast kinetic degradation profile $\left(k=6.5 \times 10^{-3} \mathrm{~min}^{-1}\right)$ with $\mathrm{O}_{3} / \mathrm{UV} / \mathrm{H}_{2} \mathrm{O}_{2}$ and being reported as an economical process $\left(1.31 € \mathrm{~m}^{-3} \mathrm{~g}^{-1}\right.$ of TOC mineralized under optimized conditions) (Lucas et al., 2010). The process behind recovering high-value phenolic compounds in vinasse, present at a concentration within the region of $600 \mathrm{mg} \mathrm{L}^{-1}$, is likely to be economically not feasible (Santos et al., 2003).

The combination of AOP with other forms of value addition to vinasse is also a research and commercial opportunity. A study conducted by Siles et al. (2011) evaluated the serialization of short-retention time ozonation, which was responsible to a decrease in over $50 \%$ of phenols, with anaerobic digestion (AD). Pretreated vinasse had anaerobic degradability of around $80 \%$ of the total COD, with enhanced methane yield coefficients and methane production rates enhanced by 13.6 and $41.2 \%$ when compared to raw vinasse (Siles et al., 2011). Potential studies with phototrophic microorganisms for production of value-added 
compounds could be coupled with AOP focused on color removal. Fagier et al. (2016) evaluated $\mathrm{Fe}^{2+}$-activated persulfate and peroxymonosulfate oxidation on vinasse to which an addition of $15 \mathrm{~g} \mathrm{~L}^{-1}$ of coagulant provided over $70 \%$ total organic carbon removal, and near $100 \%$ of $\mathrm{UV}_{254}$ and color removal, which lowers the toxicity levels for phototrophic microorganisms. AOP consist on a series of mature and well-understood steps that can help detoxify vinasse to further utilization and value addition, such as production of protein-rich microbial biomass.

\section{AD OF VINASSE: OPERATION, ENERGY GENERATION, AND DIGESTATE USE}

Anaerobic digestion is a common practice in the current drygrind corn-to-ethanol industry, being responsible to generate energy and degrade complex organic matter present in the corn stillage (Reis et al., 2017). Despite the composition of sugarcane vinasse differing significantly from wastewaters with high carbon load to which $\mathrm{AD}$ processes are ubiquitous and profitable, the possibility of decreasing the negative impacts to vinasse application in soil usage accelerated the research and development of AD in sugarcane vinasse. The first industrial application in Brazil was built in the 1990s and consisted of an upflow anaerobic sludge blanket (UASB) reactor in São Martinho mill with a capacity of 5,000 $\mathrm{m}^{3}$ (Souza et al., 1992). The biogas generated from the UASB reactor was used on the drying process of yeast.

The use of $\mathrm{AD}$ in sugarcane vinasse is characterized according the number of steps, process temperature, and reactor design (Rajeshwari et al., 2000). The use of digestate vinasse was used to cultivate the microalgae Chlorella vulgaris (Marques et al., 2013; Candido and Lombardi, 2017) and Neochloris oleoabundans (Olguín et al., 2015). Initially, research shows that vinasse was highly toxic to C. vulgaris at concentrations greater than $4 \%$, reaching allowable concentrations of about $8.6 \%$ after treatment (Marques et al., 2013). C. vulgaris, a widely used species in accumulation of valuable microbial lipids (Reis et al., 2014b), was able to achieve specific growth rates of 0.76 day $^{-1}$, higher than the control experiments in nutrient sufficient medium $\left(0.53\right.$ day $\left.^{-1}\right)$ (Marques et al., 2013). The use of AD can represent a feasible opportunity for making vinasse an appropriate cultivation medium for microbial cultivation, such as in the use of fungi with resilience to unfavorable conditions of growth (Reis et al., 2014a). N. oleoabundans was able to grow on supplementation of vinasse up to $8 \%$, with addition of sodium bicarbonate, achieving lipid concentrations up to $38.5 \%$, high $\mathrm{N}-\mathrm{NH}_{4}^{+}$removal (85.2\%), and high flocculation efficiency (42\% after $30 \mathrm{~min}$ ) (Olguín et al., 2015).

Due to the high sulfur composition of vinasse, $\mathrm{AD}$ produces a sulfur-rich biogas (Barrera et al., 2013), which could be highly corrosive to the burners by the production of $\mathrm{SO}_{2}$. Removal of $\mathrm{SO}_{\mathrm{x}}$ from biogas can be accomplished, among other technologies, through physical processes, such as sulfur-specific membrane filters, or through biological processes (Barrera et al., 2014). Lebrero et al. (2016) evaluated biotrickling filters (BTFs) and algalbacterial photobioreactors (PBRs) as alternative to membrane removal. Both BTF and PBR constitute removal efficiencies greater than $98 \%$, with elimination capacities as high as $26 \mathrm{~g}$ $\mathrm{S}-\mathrm{H}_{2} \mathrm{~S} \mathrm{~m}^{-3} \mathrm{~h}^{-1}$. BTF showed impressive robustness as it was completed revived after a 15-day shut down, and it was able to utilize the nutrients from vinasse, with exogenous nitrate addition (Lebrero et al., 2016). Lebrero et al. (2016) also reported that PBR supported $\mathrm{CO}_{2}$ removal of $23 \pm 11.8 \%$, increasing to $62 \%$ at $\mathrm{pH}$ of 8.1, with an overall fixation rate of $285 \mathrm{mg} \mathrm{CO}_{2} \mathrm{~L}^{-1} \mathrm{day}^{-1}$, thus, it could be coupled with a BTF to upgrade AD-generated biogas, removing inert gases and sulfur-rich compounds. Overall, $\mathrm{AD}$ of vinasse could generate approximately 4.5 MW yearly, which would correspond to over 14.5 million $\mathrm{m}^{3}$ of biogas, with concentrations of $60 \% \mathrm{CH}_{4}$, replacing up to $12 \%$ of the bagasse from burning to combined heat and power operations (Moraes et al., 2014). AD in a large-scale sugarcane ethanol plant has a potential of supplying electricity to a city of 130,000 inhabitants or a replacement up to $40 \%$ of the annual diesel supply in the agricultural energy requirements of a sugarcane biorefinery (Moraes et al., 2014). Therefore, optimization and widespread use of AD in sugarcane ethanol plants still remain as opportunities.

\section{CONCLUSION AND FUTURE DIRECTIONS}

While for many waste sources, a broad literature may be available (e.g., municipal wastewater), for others, references are scarcer and many opportunities are still under-performed-such is the case for sugarcane vinasse. The use of traditional practices, such as fertirrigation, may cause environmental issues in water and soil quality, and the use of more robust approaches must be a practical solution for vinasse management. Fertirrigation is often a practice that provides a false impression of solving the problem of vinasse disposal. The use of $\mathrm{AD}$ is an underperformed process in sugarcane plants and could significantly increase the energy output, while reducing the amount of water used within a plant. AOP can help decrease the toxicity of vinasse and can be used as a pretreatment for microbial growth, which could generate high throughput of value-added chemicals. Treatment of vinasse prior to recycling it as fertilizer and irrigation water would potentially lower the environmental impact of applying a nutrient-rich suspension to soils. Thus, vinasse management is an issue in ethanol plants in Brazil, home to the second largest ethanol production in the world, which represents a realm of hidden opportunities for mature technologies.

\section{AUTHOR CONTRIBUTIONS}

CR is the first author of the paper. He conceptualized the idea, analyzed the references, and drafted the paper. $\mathrm{BH}$ serves as the Ph.D. advisor for CR and worked with him together on designing and finalizing the paper.

\section{FUNDING}

Authors are grateful for the support of MnDRIVE-Global Food Ventures for the funding support. CR acknowledges MnDRIVEUMII and CAPES, Ministry of Education of Brazil (BEX 13252/13-5) for his fellowship. 


\section{REFERENCES}

Abioye, O. P. (2011). "Biological remediation of hydrocarbon and heavy metals contaminated soil," in Soil Contamination, ed. S. Pascucci, Rijeka: INTECH. Available from: https://www.intechopen.com/books/soilcontamination/biological-remediation-of-hydrocarbon-and-heavy-metalscontaminated-soil

Alcoforado de Moraes, M. M. G., Cai, X., Ringler, C., Albuquerque, B. E., Vieira da Rocha, S. P., and Amorim, C. A. (2009). Joint water quantity-quality management in a biofuel production area-integrated economic-hydrologic modeling analysis. J. Water Resour. Plann. Manag. 136, 502-511. doi:10.1061/(ASCE) WR.1943-5452.0000049

Andreozzi, R., Caprio, V., Insola, A., and Marotta, R. (1999). Advanced oxidation processes (AOP) for water purification and recovery. Catal. Today 53, 51-59. doi:10.1016/S0920-5861(99)00102-9

Badger, P. C. (2002). "Ethanol from cellulose: a general review," in Trends New Crops and New Uses, eds J. Janick and A. Whipkey, Alexandria, VA: ASHS Press.

Barrera, E. L., Spanjers, H., Dewulf, J., Romero, O., and Rosa, E. (2013). The sulfur chain in biogas production from sulfate-rich liquid substrates: a review on dynamic modeling with vinasse as model substrate. J. Chem. Technol. Biotechnol. 88, 1405-1420. doi:10.1002/jctb.4071

Barrera, E. L., Spanjers, H., Romero, O., Rosa, E., and Dewulf, J. (2014). Characterization of the sulfate reduction process in the anaerobic digestion of a very high strength and sulfate rich vinasse. Chem. Eng. J. 248, 383-393. doi:10.1016/j.cej. 2014.03.057

Benke, M., Mermut, A., and Chatson, B. (1998). Carbon-13 CP/MAS NMR and DR-FTIR spectroscopic studies of sugarcane distillery waste. Can. J. Soil Sci. 78, 227-236. doi:10.4141/S97-036

Brethauer, S., and Wyman, C. E. (2010). Review: continuous hydrolysis and fermentation for cellulosic ethanol production. Bioresour. Technol. 101, 4862-4874. doi:10.1016/j.biortech.2009.11.009

Cammarota, M. C., Camporese, S. E. F., Absai, D. A. C. G., Larissa De, C. A., Groposo, S. C. J., De Castro, A. M., et al. (2012). Method for Producing EnergyRich Gases from Lignocellulosic Material Streams. Google patents.

Candido, C., and Lombardi, A. T. (2017). Growth of Chlorella vulgaris in treated conventional and biodigested vinasses. J. Appl. Phycol. 29, 45-53. doi:10.1007/ s10811-016-0940-2

Christofoletti, C. A., Escher, J. P., Correia, J. E., Marinho, J. F. U., and Fontanetti, C. S. (2013). Sugarcane vinasse: environmental implications of its use. Waste Manag. 33, 2752-2761. doi:10.1016/j.wasman.2013.09.005

Có Júnior, C., Marques, M. O., and Tasso Júnior, L. C. (2008). Sugarcane technological parameters affected by sewage sludge and vinasse added in soil for four consecutive years. Eng. Agric. 28, 196-203. doi:10.1590/S0100-69162008000100020

Constabel, C. P., and Ryan, C. A. (1998). A survey of wound-and methyl jasmonateinduced leaf polyphenol oxidase in crop plants. Phytochemistry 47, 507-511. doi:10.1016/S0031-9422(97)00539-6

Cortez, L., Magalhães, P., and Happi, J. (1992). Principais subprodutos da agroindústria canavieira e sua valorização. Rev. Bras. Energ. 2, 111.

Della-Bianca, B. E., Basso, T. O., Stambuk, B. U., Basso, L. C., and Gombert, A. K. (2013). What do we know about the yeast strains from the Brazilian fuel ethanol industry? Appl. Microbiol. Biotechnol. 97, 979-991. doi:10.1007/s00253012-4631-x

dos Santos, J. D., da Silva, A. L. L., da Luz Costa, J., Scheidt, G. N., Novak, A. C., Sydney, E. B., et al. (2013). Development of a vinasse nutritive solution for hydroponics. J. Environ. Manage. 114, 8-12. doi:10.1016/j.jenvman.2012.10.045

Dowd, M. K., Johansen, S. L., Cantarella, L., and Reilly, P. J. (1994). Low molecular weight organic composition of ethanol stillage from sugarcane molasses, citrus waste, and sweet whey. J. Agric. Food Chem. 42, 283-288. doi:10.1021/ if00038a011

Egounlety, M., and Aworh, O. (2003). Effect of soaking, dehulling, cooking and fermentation with Rhizopus oligosporus on the oligosaccharides, trypsin inhibitor, phytic acid and tannins of soybean (Glycine max Merr.), cowpea (Vigna unguiculata L. Walp) and groundbean (Macrotyloma geocarpa Harms). J. Food Eng. 56, 249-254. doi:10.1016/S0260-8774(02)00262-5

España-Gamboa, E., Mijangos-Cortes, J., Barahona-Perez, L., DominguezMaldonado, J., Hernández-Zarate, G., and Alzate-Gaviria, L. (2011). Vinasses: characterization and treatments. Waste Manag. Res. 29, 1235-1250. doi:10.1177/ $0734242 X 10387313$
España-Gamboa, E., Vicent, T., Font, X., Dominguez-Maldonado, J., CantoCanché, B., and Alzate-Gaviria, L. (2017). Pretreatment of vinasse from the sugar refinery industry under non-sterile conditions by Trametes versicolor in a fluidized bed bioreactor and its effect when coupled to an UASB reactor. J. Biol. Eng. 11, 6. doi:10.1186/s13036-016-0042-3

España-Gamboa, E., Vicent, T., Font, X., Mijangos-Cortés, J., Canto-Canché, B., and Alzate, L. (2015). Phenol and color removal in hydrous ethanol vinasse in an air-pulsed bioreactor using Trametes versicolor. J. Biochem. Technol. 6, 982-986.

Eykelbosh, A. J., Johnson, M. S., and Couto, E. G. (2015). Biochar decreases dissolved organic carbon but not nitrate leaching in relation to vinasse application in a Brazilian sugarcane soil. J. Environ. Manage. 149, 9-16. doi:10.1016/j.jenvman. 2014.09.033

Fadel, M., Zohri, A.-N. A., Makawy, M., Hsona, M., and Abdel-Aziz, A. (2014). Recycling of vinasse in ethanol fermentation and application in Egyptian distillery factories. Afr. J. Biotechnol. 13, 4390-4398. doi:10.5897/AJB2014.14083

Fagier, M., Ali, E., Tay, K., and Abas, M. (2016). Mineralization of organic matter from vinasse using physicochemical treatment coupled with $\mathrm{Fe}^{2+}$-activated persulfate and peroxymonosulfate oxidation. Int. J. Environ. Sci. Technol. 13, 1189-1194. doi:10.1007/s13762-016-0963-x

Ferreira, J. A., Lennartsson, P. R., and Taherzadeh, M. J. (2015). Production of ethanol and biomass from thin stillage by Neurospora intermedia: a pilot study for process diversification. Eng. Life Sci. 15, 751-759. doi:10.1002/elsc. 201400213

Filoso, S., do Carmo, J. B., Mardegan, S. F., Lins, S. R. M., Gomes, T. F., and Martinelli, L. A. (2015). Reassessing the environmental impacts of sugarcane ethanol production in Brazil to help meet sustainability goals. Renew. Sustain. Energ. Rev. 52, 1847-1856. doi:10.1016/j.rser.2015.08.012

FitzGibbon, F., Singh, D., McMullan, G., and Marchant, R. (1998). The effect of phenolic acids and molasses spent wash concentration on distillery wastewater remediation by fungi. Process Biochem. 33, 799-803. doi:10.1016/S0032-9592 (98)00050-8

Goldemberg, J., Coelho, S. T., and Guardabassi, P. (2008). The sustainability of ethanol production from sugarcane. Energy Policy 36, 2086-2097. doi:10.1016/j. enpol.2008.02.028

Gómez, J., and Rodríguez, O. (2000). Effects of vinasse on sugarcane (Saccharum officinarum) productivity. Rev. Fac. Agron. 17, 318-326.

Jiang, Z.-P., Li, Y.-R., Wei, G.-P., Liao, Q., Su, T.-M., Meng, Y.-C., et al. (2012). Effect of long-term vinasse application on physico-chemical properties of sugarcane field soils. Sugar Tech 14, 412-417. doi:10.1007/s12355-012-0174-9

Lebrero, R., Toledo-Cervantes, A., Muñoz, R., del Nery, V., and Foresti, E. (2016). Biogas upgrading from vinasse digesters: a comparison between an anoxic biotrickling filter and an algal-bacterial photobioreactor. J. Chem. Technol. Biotechnol. 91, 2488-2495. doi:10.1002/jctb.4843

Lim, C., and Akiyama, D. (1992). Full-fat soybean meal utilization by fish. Asian Fish. Sci. 5, 181-197.

Lucas, M. S., Peres, J. A., and Puma, G. L. (2010). Treatment of winery wastewater by ozone-based advanced oxidation processes $\left(\mathrm{O}_{3}, \mathrm{O}_{3} / \mathrm{UV}\right.$ and $\left.\mathrm{O}_{3} / \mathrm{UV} / \mathrm{H}_{2} \mathrm{O}_{2}\right)$ in a pilot-scale bubble column reactor and process economics. Sep. Purif. Technol. 72, 235-241. doi:10.1016/j.seppur.2010.01.016

Mariano, A. P., Crivelaro, S. H. R., Angelis, D. D. F. D., and Bonotto, D. M. (2009). The use of vinasse as an amendment to ex-situ bioremediation of soil and groundwater contaminated with diesel oil. Braz. Arch. Biol. Technol. 52, 1043-1055. doi:10.1590/S1516-89132009000400030

Marques, S. S. I., Nascimento, I. A., de Almeida, P. F., and Chinalia, F. A. (2013). Growth of Chlorella vulgaris on sugarcane vinasse: the effect of anaerobic digestion pretreatment. Appl. Biochem. Biotechnol. 171, 1933-1943. doi:10.1007/ s12010-013-0481-y

Moraes, B. S., Junqueira, T. L., Pavanello, L. G., Cavalett, O., Mantelatto, P. E., Bonomi, A., et al. (2014). Anaerobic digestion of vinasse from sugarcane biorefineries in Brazil from energy, environmental, and economic perspectives: profit or expense? Appl. Energy 113, 825-835. doi:10.1016/j.apenergy.2013.07.018

Moraes, B. S., Zaiat, M., and Bonomi, A. (2015). Anaerobic digestion of vinasse from sugarcane ethanol production in Brazil: challenges and perspectives. Renew. Sustain. Energ. Rev. 44, 888-903. doi:10.1016/j.rser.2015.01.023

Moran-Salazar, R., Sanchez-Lizarraga, A., Rodriguez-Campos, J., Davila-Vazquez, G., Marino-Marmolejo, E., Dendooven, L., et al. (2016). Utilization of vinasses as soil amendment: consequences and perspectives. Springerplus 5, 1-11. doi:10.1186/s40064-016-2410-3 
Nair, R. B., and Taherzadeh, M. J. (2016). Valorization of sugar-to-ethanol process waste vinasse: a novel biorefinery approach using edible ascomycetes filamentous fungi. Bioresour. Technol. 221, 469-476. doi:10.1016/j.biortech.2016. 09.074

Nitayavardhana, S., Issarapayup, K., Pavasant, P., and Khanal, S. K. (2013). Production of protein-rich fungal biomass in an airlift bioreactor using vinasse as substrate. Bioresour. Technol. 133, 301-306. doi:10.1016/j.biortech.2013. 01.073

Nitayavardhana, S., and Khanal, S. K. (2010). Innovative biorefinery concept for sugar-based ethanol industries: production of protein-rich fungal biomass on vinasse as an aquaculture feed ingredient. Bioresour. Technol. 101, 9078-9085. doi:10.1016/j.biortech.2010.07.048

Olguín, E. J., Dorantes, E., Castillo, O. S., and Hernández-Landa, V. J. (2015). Anaerobic digestates from vinasse promote growth and lipid enrichment in Neochloris oleoabundans cultures. J. Appl. Phycol. 27, 1813-1822. doi:10.1007/ s10811-015-0540-6

Parnaudeau, V., Condom, N., Oliver, R., Cazevieille, P., and Recous, S. (2008). Vinasse organic matter quality and mineralization potential, as influenced by raw material, fermentation and concentration processes. Bioresour. Technol. 99, 1553-1562. doi:10.1016/j.biortech.2007.04.012

Paz-Pino, O. L., Barba-Ho, L. E., and Marriaga-Cabrales, N. (2014). Vinasse treatment by coupling of electro-dissolution, hetero-coagulation and anaerobic digestion. Dyna 81, 102-107. doi:10.15446/dyna.v81n187.38922

Penatti, C., Cambria, S., Boni, P., Arruda, F., and Manoel, L. (1988). Efeitos da aplicação de vinhaça e nitrogênio na soqueira da cana-de-açúcar. Bol. Tec. Copersucar 44, 32-38.

Prata, F., Lavorenti, A., Regitano, J. B., and Tornisielo, V. L. (2001). Degradação e sorção de ametrina em dois solos com aplicação de vinhaça. Pesq. Agropec. Bras. 36, 975-981. doi:10.1590/S0100-204X2001000700007

Rajeshwari, K., Balakrishnan, M., Kansal, A., Lata, K., and Kishore, V. (2000). Stateof-the-art of anaerobic digestion technology for industrial wastewater treatment. Renew. Sustain. Energ. Rev. 4, 135-156. doi:10.1016/S1364-0321(99)00014-3

Ramirez, N. N. V., Farenzena, M., and Trierweiler, J. O. (2014). Growth of microalgae Scenedesmus sp in ethanol vinasse. Braz. Arch. Biol. Technol. 57, 630-635. doi:10.1590/S1516-8913201401791

Reis, C. E., Zhang, J., and Hu, B. (2014a). Lipid accumulation by pelletized culture of Mucor circinelloides on corn stover hydrolysate. Appl. Biochem. Biotechnol. 174, 411-423. doi:10.1007/s12010-014-1112-y

Reis, C. E. R., de Souza Amaral, M., Loures, C. C. A., da Rós, P. C. M., Hu, B., Izário Filho, H. J., et al. (2014b). "Microalgal feedstock for bioenergy: opportunities and challenges," in Biofuels in Brazil, eds S. S. Silva and A. K. Chandel (Cham: Springer), 367-392.

Reis, C. E. R., Rajendran, A., and Hu, B. (2017). New technologies in value addition to the thin stillage from corn-to-ethanol process. Rev. Environ. Sci. Biotechnol. 16, 175-206. doi:10.1007/s11157-017-9421-6
Rocha, M. H., Lora, E. E. S., and Venturini, O. J. (2007). Life cycle analysis of different alternatives for the treatment and disposal of ethanol vinasse. Proc. Int. Soc. Sugar Cane Technol. 26, 108-114.

Santos, M., Fernández Bocanegra, J., Martín Martín, A., and García García, I. (2003). Ozonation of vinasse in acid and alkaline media. J. Chem. Technol. Biotechnol. 78, 1121-1127. doi:10.1002/jctb.908

Siles, J., García-García, I., Martín, A., and Martín, M. (2011). Integrated ozonation and biomethanization treatments of vinasse derived from ethanol manufacturing. J. Hazard. Mater. 188, 247-253. doi:10.1016/j.jhazmat.2011.01.096

Souza, M., Fuzaro, G., and Polegato, A. (1992). Thermophilic anaerobic digestion of vinasse in pilot plant UASB reactor. Water Sci. Technol. 25, 213-222.

Sparovek, G., Barretto, A., Berndes, G., Martins, S., and Maule, R. (2009). Environmental, land-use and economic implications of Brazilian sugarcane expansion 1996-2006. Mitigation Adapt. Strateg. Global Change 14, 285-298. doi:10.1007/ s11027-008-9164-3

Todokoro, T., Fukuda, K., Matsumura, K., Irie, M., and Hata, Y. (2015). Production of the natural iron chelator deferriferrichrysin from Aspergillus oryzae and evaluation as a novel food-grade antioxidant. J. Sci. Food Agric. 96:2998-3006. doi:10.1002/jsfa.7469

Valsechi, O., and Gomes, F. P. (1954). Solos incorporados de vinhaça e seu teor de bases. An. Esc. Super. Agric. Luiz Queiroz 11, 136-158. doi:10.1590/S007112761954000100012

Walter, A., Dolzan, P., Quilodrán, O., de Oliveira, J. G., da Silva, C., Piacente, F., et al. (2011). Sustainability assessment of bio-ethanol production in Brazil considering land use change, GHG emissions and socio-economic aspects. Energy Policy 39, 5703-5716. doi:10.1016/j.enpol.2010.07.043

Yang, X., Wang, K., Wang, H., Zhang, J., and Mao, Z. (2016). Ethanol fermentation characteristics of recycled water by Saccharomyces cerevisiae in an integrated ethanol-methane fermentation process. Bioresour. Technol. 220, 609-614. doi:10.1016/j.biortech.2016.08.040

Conflict of Interest Statement: The authors declare that the research was conducted in the absence of any commercial or financial relationships that could be construed as a potential conflict of interest.

The reviewer, RH, and handling editor declared their shared affiliation, and the handling editor states that the process nevertheless met the standards of a fair and objective review.

Copyright (C) 2017 Rodrigues Reis and Hu. This is an open-access article distributed under the terms of the Creative Commons Attribution License (CC BY). The use, distribution or reproduction in other forums is permitted, provided the original author(s) or licensor are credited and that the original publication in this journal is cited, in accordance with accepted academic practice. No use, distribution or reproduction is permitted which does not comply with these terms. 